\title{
DEVELOPMENT OF TERRITORIES USING MODERN MANAGEMENT AND MARKETING TOOLS IN THE CONDITIONS OF GLOBAL CHALLENGES AND THREATS
}

Bolila S. Yu.

\section{INTRODUCTION}

Today's realities have demonstrated the unpreparedness of modern economic systems for global challenges and threats due to large-scale adverse events such as pandemics, global warming and climate change, natural disasters, depletion of natural resources, environmental pollution and, as a result, adverse environmental externalities. This has quite serious consequences for entire industries and leads to a redistribution of competitive positions, both at the global and national levels. This also applies to issues of territorial development. At the same time, some territories have the opportunity for sustainable development due to flexibility, ability to adapt quickly to change, form positive image characteristics and create conditions for attracting consumers of various goods and services that can provide a particular area or region. This raises the issue of regional marketing management as a specific type of public management activities carried out to identify and promote the interests of the population and the territorial community to address specific challenges of regional development by creating competitive advantages, attracting investment based on the brand of the territory. Today, society is faced the need to move to a model of socio-economic development, when meeting the vital needs of the current generation does not deprive them of a chance to meet the needs of future descendants, save resources for future generations and ensure environmental quality and ecological regeneration. If the regions pay enough attention to these issues, they have every chance to form a positive image, to be in trend, in condition that the values of consumption in society and in the minds of each customer change.

Achieving sustainable development of the region is possible when it meets the socio-economic criteria: economic efficiency, environmental sustainability, and social prosperity. Indicative in this direction is the development of the region through tourist destinations that focus on the rational use of nature and which directly or indirectly affect not only the 
economy of the region, but also its social policy, culture, traditions, lifestyle, health of the nation, natural environment, etc ${ }^{1}$.

Therefore, tourism, and especially ecological and green should be considered as one of the tools that contribute to the development of the region and form the brand of the territory.

Branding technologies for shaping the region's image are an effective means of growing its reputational capital, they increase investment attractiveness and help strengthen competitive positions in the fight for limited financial resources between territories, so they are important in today's global challenges and threats.

\section{Modern aspects of management of territories and territorial communities to increase their competitiveness}

Today, in market conditions, taking into account the best practices of management and marketing becomes especially important for the development of territories and territorial communities.

The modern system of views on governance was formed under the influence of changes in world social and economic development. New opportunities for business growth have emerged, especially in industries that focus on meeting the immediate needs of people. In these conditions, such characteristics of business as flexibility, dynamism, adaptability, which is relevant in the management of both territories and local communities, have become essential.

There is a need for new management methods that would take into account modern realities, be based on systemic and situational approaches to management and would be result-oriented. Today, the leadership of the region and the leaders of territorial communities in the countryside face serious challenges.

A modern manager in modern conditions must be a qualified manager and know well: general theoretical foundations of management and legal disciplines to the extent necessary for professional management in the field of regional government and local self-government, strengthening the rule of law and impeccable performance of their duties; general, specific and practical problems in the field of social and humanitarian policy that take place in territorial communities; the content of the main economic processes at the level of territorial communities (region) in the conditions of economic transformation; general theoretical and legal principles of management of territorial communities and distribution of spheres of activity in the process of

${ }^{1}$ Lanza A., Markandya A., Pigliaru F. (2005) The Economics of Tourism and Sustainable Development. Cheltenham, UK; Northampton, MA, USA. P. 8. 
their management; ethics and culture of business and political communication; functions of the region in the field of financial and budget management; organization, forms and methods of work of territorial self-government bodies; problems of social protection of members of the territorial community; basic legislative provisions on state-church relations, issues of national minorities and population migration; basics of rational nature management and environmental protection; basic measures to prevent emergencies and reduce their losses in the event of their occurrence; basics of personnel policy; management decision-making mechanisms; basics of organizational and legal work; basics of office work; basics of operation of digital technologies and modern means of telecommunication.

The head of the territorial community must demonstrate the skills of a professional community manager, namely: determine the priorities of the development of the territory; achieve the effectiveness and efficiency of management decisions; promptly and effectively process information and at the appropriate level to prepare draft decisions and ensure effective control over their implementation; systematically improve their professional skills; resolve conflict situations and manage communication technologies; be a leader ${ }^{2}$.

Leaders of territorial communities, especially in rural areas, are characterized by an expanded range of skills and knowledge of analytical, forecasting and coordination activities, which is due to the development of strategies and tactics of local governments under their control. Relevant skills and knowledge of organizational and support functions include the ability to create and implement mechanisms of regulatory, logistical, economic, financial and other types of ensuring the functioning of the structures managed by them. Coordination and control functions require a set of skills and knowledge that come with professional experience, the ability to properly use the existing legal and regulatory framework ${ }^{3}$.

The set of listed functions requires certain levels of competence of the head of the territorial community. The first level of competence, which regulates the implementation of standard operations and certain procedures, is no longer enough for a modern head of a territorial community. There is a need for professional leaders who are interested in developing their own style of

${ }^{2}$ Bilenchuk P.D., Kravchenko V.V., Pidmogilny M.V.(2000) Mistseve amovriaduvannia v Ukraini [Local self-government in Ukraine].Munitsypalne pravo [Municipal law]. Kyiv : Atika, 304 p.

${ }^{3}$ Chemeris A.O., Shevchuk P.I., Gural P.F. (2002) Mistseve samovriaduvannia : monohrafiia. Kn. 1. Orhanizatsiia roboty silskoho, selyshchnoho holovy. Lviv : [Local government: Monograph. Book 1. Organization of work of the village, settlement head]. Lviv : Liha-Pres, 390 p. 
problem solving, and consequently in expanding their knowledge, and leaders - creative individuals who demonstrate the art of management.

The head of the second level of competence focuses on forming a personal attitude to what is happening. In the process of solving problems, the leader of this level may have creative ideas; he can apply fundamentally new approaches to solving old and new problems. Factors such as personal standards, values, and moral norms begin to take full effect in the manager at the third level of competence.

Quite often personal values are in conflict with those that exist in the community. To solve these issues, community leaders must make every effort to unite community members, to make them aware of the importance of unity. Bringing together active and conscious members of the community, its leader must take care of cultural, educational and patriotic work among the population on a daily basis. With high spirituality of community members, it is easy to overcome any difficulties that arise in the process of their life. In conditions of unity and harmony, the territorial community will be able to solve complex economic issues on the way to the development of the territory. In our country there are isolated successful examples of territorial communities that are able to support the development of peasant unions, farms, entrepreneurs, innovative technologies and more.

Knowledge of the latest management concepts in management and marketing can be useful for the leaders of the territorial community: technocratic management; modern behaviorism, the product of which was the theory of human capital; goal management (strategic management); quality management according to the TQM system; "kanban" systems; entrepreneurship, reengineering, the concept of internal markets of corporations, the theory of alliances, modern institutionalism, socio-ethical marketing, partnership marketing, holistic marketing, etc.

In addition, for a modern leader it is important today to increase the competitiveness and development of local communities to proceed from the position of territorial marketing.

Territorial marketing is an advanced idea, a philosophy of territory development that will meet the needs and expectations of target markets. The main task of marketing of the territory is to determine what resources are available to competing regions, and to find ways to differentiate and position their region in such a way as to stand out in the minds of target groups. Territory marketing is not just about promoting the region in the market. Promotion alone does not benefit the depressed region, but instead helps potential buyers identify its plight as soon as possible. According to scientists, marketing of the territory is a special type of public management activity carried out in order to identify and promote the interests of the population of the territory to solve specific problems of development, creation, maintenance 
and / or change of relations and behavior of residents and nonresidents, other business entities and management structures in relation to a specific area ${ }^{4}$. Continuing the idea, regional marketing is a certain way of thinking and actions of regional leaders, a new business philosophy of active entrepreneurship in the region, based on the desire to meet the identified needs of specific people, consumer groups, businesses in the region and beyond its borders (action in selected markets) in the relevant goods - finished products, technology, services, information, etc ${ }^{5}$.

It should be noted that the region as a territorial and organizational unit in terms of marketing approaches is a special object, which differs in a set of initial marketing factors, marketing actors and even target groups.

The need for further development of regional marketing as a basic theory of territorial marketing is explained primarily by the fact that this requires dynamic processes of regionalization, increasing the role of the region as an independent market entity and changing its position in the socio-political environment. The main goals of marketing for the development of the territory are: increasing/maintaining the competitiveness of enterprises located in the region; improving the degree of identification of citizens with their territory of residence; attraction of new enterprises to the region; increasing the level of popularity of the territory outside it.

Marketing of the region, acting as an integral part of regional economic policy; includes the development and implementation of a long-term concept of integrated economic and social development of the territory.

An extremely important task for the development of territories and territorial communities, taking into account the strategic marketing approach, is to determine their potential and ways of its effective implementation. The following means should be used: system approach (consideration of the territorial community as a system that is a set of interconnected elements); analysis of various elements of the system; identification of opportunities and threats that exist in the system and in the external environment; survey of residents of the settlement (or points that are part of the community); monitoring the views, interests and attitudes of residents; modeling the prospects for the development of the territorial community and the territory in which it is represented.

\footnotetext{
${ }^{4}$ Chemeris A.O., Shevchuk P.I., Gural P.F.(2002) Mistseve samovriaduvannia: Monohrafiia. Kn. 1. Orhanizatsiia roboty silskoho, selyshchnoho holovy. Lviv: [Local government : monograph. Book 1. Organization of work of the village, settlement head]. Lviv : Liha-Pres, 390 p.

${ }^{5}$ Bozhkova V.V. (2005) Zastosuvannia nekomertsiinoho marketynhu na munitsypalnomu ta rehionalnomu rivniakh [Application of non-commercial marketing at the municipal and regional levels]. Marketynh i reklama [Marketing and advertising]. № 9, pp. 38-43.
} 
The potential of the territorial community is a complex concept, its components are: geographical, demographic, economic, environmental, social (including cultural), management. Their combination creates a unique situation for each community and is the basis for further development. The description of the potential is performed on the basis of documented data and contains information on separately defined indicators for each component.

Generalization of information makes it possible to justify promising areas of development of the territorial community. The transformation of certain types of potential should be planned on the basis of a population survey.

For the development of territories it is important to define strategic guidelines, examples of which today are:

- solving the problems of preserving the natural resource potential of the territories, namely: ensuring constant control over the compliance of subsoil users with development projects and technological schemes in the development of mineral deposits; development of protected areas for biodiversity conservation, expansion of existing and creation of new nature reserves; financing of activities on limitation, placement and disposal of waste; prevention of pollution of rivers, lakes, reservoirs and other hydrological objects and maintenance of their favorable hydrological condition; introduction of modern technologies of forestry; reproduction of indigenous stands and indigenous faunal complexes; introduction of ecological and economic levers of rational use of natural resources; formation of environmental funds to finance environmental activities; development of agro-environmental monitoring to preserve and restore land resource potential; development of green tourism and health services, which will be a significant source of income in the budgets of rural households and local governments;

- introduction of the system of organic agricultural production, namely: standardization of principles and standards of organic agricultural production; advocacy measures for the spread of organic production; coordination of work in the production system with natural cycles and living systems of soils, flora and fauna; preservation and improvement of soil fertility and biological activity with the help of local cultural, biological and mechanical methods; application of organic fertilizers; preservation of agro;

- and biodiversity in enterprises, their environment through the use of a sustainable system of production and protection of wildlife; promoting the responsible use and conservation of water resources with all their living organisms; formation and development of social responsibility of commodity producers in solving problems of modern land use and increase of social orientation of agro-industrial production on the basis of development of cluster systems on production of agricultural products with deepened specialization and concentration of agro-industrial production according to 
features of rural territories; bringing the production of plant and animal protection products, biological products, compound feeds and quality control in line with international standards, for which to organize appropriate laboratories that will assess the quality of these drugs; introduction of a product quality management system, which should be based on the international system of standardization and quality improvement of crop and livestock products; control of field clogging by quarantine weeds - ragweed; bringing the production of plant and animal protection products, biological products, compound feeds and quality control in line with international standards, for which to organize appropriate laboratories that will assess the quality of these drugs; introduction of a product quality management system, which should be based on the international system of standardization and quality improvement of crop and livestock products; control of field clogging by quarantine weeds - ragweed; stimulation of local and regional production and movement of products to consumers; creating a harmonious balance between crop production and animal husbandry; introduction of ecological logistics in the agro-sphere: optimization of transportation for the purpose of rational use of resources; introduction of quality management systems, environmental management of the use of economically feasible materials and methods of product delivery to the consumer; use of biofuels and renewable energy sources, cost and quality control in supply chains, etc.; providing such conditions in which domestic animals show natural behavior; use of packaging materials that are subject to recycling or biodegradable; compliance with the optimal size of agricultural production, which will make possible a significant (25-30\%) reduction in production costs and increase productivity; providing information and consulting assistance by agricultural advisory services on scientific achievements in the field of organic production technologies, on the market of products, access to foreign markets of organic products, plant protection, arrangement of different types of proper crop rotations, agricultural techniques and compliance with organic fertilizers; organization of sales cooperatives of organic producers; agro-insurance of ecological agricultural production through the creation of a state agricultural insurance company and the creation of insurance companies on a cooperative basis, where the founders and shareholders will be producers, processors and sellers of ecologically clean agricultural products.

Thus, the assessment of the potential of the territory and prospects of territorial communities is based on the approaches used in strategic management, marketing and quality management, adapted to the conditions of the basic level of local government and allow determining strategic directions of regional development. 


\section{Formation of the image of the destination as a component of regional development}

One of the tools of marketing the territory, the purpose of which is to raise the image of the territory, raise awareness, increase the number of attracted investments, increase the participation of the territory in regional and state programs, is territorial branding. Its aspects and problems have been considered in the works of a number of scientists: S. Anholt ${ }^{6}, \mathrm{~S}$. Anholt ${ }^{7}$, F. Kotler, K. Asplund, D. Haider and I. Raine ${ }^{8}$, B. Baker ${ }^{9}$, K. Denmark ${ }^{10}$, R. Hovers and F. Go ${ }^{11}$, T. Moilanen and S. Rainisto ${ }^{12}$, S. Paik ${ }^{13}$.

Today, territorial branding is the most effective tool for active positioning of the region, the process of building, developing and managing a brand, the purpose of which is to create a strong and competitive region.

There is a steady tendency to consider the brand of the territory as a set of enduring values that reflect the unique original consumer characteristics of the territory and community, such that are widely known and publicly recognized and enjoy stable consumer demand. The brand is formed on the basis of a pronounced positive image of the territory, which is based on the unique ability to meet certain demands of its consumers, and which is the highest manifestation of emotional consumer preferences. At the same time, it acts as the most important factor of competitive advantages and revenues of the territory, a valuable asset of the economy.

Territory branding allows solving the problem of limited resources of the region and increase its competitiveness by informing the target audience about the competitor's identity and uniqueness of the territory.

${ }^{6}$ Anholt S. Competitive Identity: The New Brand Management for Nations, Cities and Regions. 1-st edition. Palgrave Macmillan, 2007, 160 p.

${ }^{7}$ Anholt S. Places: Identity, Image and Reputation. Palgrave Macmillan, 2009, 256 p.

${ }^{8}$ Kotler F., Asplund K., Raine I., Haider D.(2005). Marketynh mest. Privlechenie investiczij, predpriyatij, zhitelej i turistov v goroda, kommuny, regiony i strany Evropy [Place marketing. Attracting investments, enterprises, residents and tourists to cities, communes, regions and countries of Europe]. SPb. : «Stokgolmskaya shkola ekonomiki», $382 \mathrm{p}$.

${ }_{9}^{9}$ Baker B.(2007) Destination Branding for Small Cities. [1st edition]. Creative Leap Books, $192 \mathrm{p}$.

${ }^{10}$ Dinnie K. (2011) City Branding: Theory and Cases. [1 edition]. Palgrave Macmillan. 2011, 256 p.

${ }^{11}$ Govers R., Go Fr.(2009) Place Branding: Glocal, Virtual and Physical Identities, Constructed, Imagined and Experienced. Palgrave Macmillan. 2009, 256 p.

${ }^{12}$ Moilanen T., Rainisto S.(209) How to Brand Nations, Cities and Destinations: A Planning Book for Place Branding. Palgrave Macmillan, 2009, 230 p.

${ }^{13}$ Pike St. (2008) Destination Marketing: An Integrated Marketing Communication Approach. Butterworth-Heinneman, $424 \mathrm{p}$. 
The brand of the territory is a complex concept; it is not only a territorial symbol, a visual image of its perception by the consumer, but also a complex of goods and services, arts and talents demonstrated by the population, its authenticity, features of life and culture, social and infrastructural objects, specifics of small towns and rural areas with represented agricultural production, attractiveness for investors, mechanisms of public-private partnership and interaction to achieve the effect of synergy.

The competitive advantage of the territory is associated not only with its product offer, which consists of territorial products, relationships and structures of producers, intermediaries and consumers of these goods and services, but also with skillful and effective marketing. Characterization of distribution methods in the marketing of the territory is quite a difficult task, because the "place" of sale of goods (the territory) is virtually unchanged. In addition, there are almost no intermediaries in the pure form of the marketing of territories. These include some conditionally: authorities and public organizations, associations of the highest territorial level and their representatives; chambers of commerce and industry, centers of business and international trade, exhibition centers, fairs; transnational and other territorial business entities; various inter-territorial network organizational structures; mass media and communication; travel agencies; tourist information centers; vocational education institutions. The content of measures of this element of the marketing complex of the territory is to provide business information to businesses, concluding contractual relations with other territories, organizing exhibitions and fairs, informing potential and existing tourists who want to visit attractive places, etc. An important factor component of the marketing complex of the territory is promotion, which is associated with a set of marketing communications, creating an image, increasing the attractiveness of the territory, brand development and promotion. Experts note that the complex of means of marketing communications of the territory includes: traditional commercial advertising; means of accelerating and strengthening the positive reaction of government agencies and economic agents; public relations and relevant organizations for the development of territories and communities; propaganda and personal contacts.

The tourism industry is extremely important for the development of the territory, which allows ensuring the inflow of funds to solve the problems of the local population in a service economy. Therefore, the formation of the brand of the tourist destination is part of the strategy to support the brand of the territory. The research of destinations is devoted to the works of many scientists, some of them connect this concept with a specific territory that 
has administrative boundaries or has a unique character ${ }^{14}$, some emphasizes the resource capacity of the territories to provide the necessary set of services and facilities to meet the needs of visitors ${ }^{15}$. V. Framke, in his analysis, notes that the destination is a set of interests, different activities, services, infrastructure of attractions that form the identity of the place ${ }^{16}$. The researcher emphasizes that the destination has a static aspect - a place, territory and a dynamic aspect - a set of different agents, products and services that vary depending on demand.

For a marketing policy to be successful in a regional market, it cannot be pursued in one direction, such as advertising. Prerequisite for successful destination branding is diagnosis and planning, which should be carried out in cooperation with local authorities and the business community.

Precedes the branding of tourist destinations, their positioning, which can be formed: as the identity of the territory, as a well-established environment with a developed technological infrastructure that is compatible with the natural environment; as a provider of appropriate quality services that meet the needs of business and society (protection of people and property, social protection and education, medicine and health); as a recreation and entertainment area that has a number of values and offers for its own residents and tourists. In the marketing of places, a tourist destination should be considered from the standpoint of a consumer who is looking for new experiences, interesting events and entertainment, and in a pandemic, also the opportunity to turn the attention and get a safe vacation.

Let's consider these questions on an example of the Kherson area. Kherson region is a very attractive tourist destination in Ukraine. Due to its importance in today's conditions, due to the annexation of Crimea, it can be attributed not only to the regional type, but also to the national, because according to recent years for the summer holiday season, there were flows of visitors from all over Ukraine. In addition, the safety factor is also important, because the situation in the region is relatively favorable in terms of epidemiological morbidity. Kherson region has a huge number of natural complexes with diverse flora and fauna, rocks, soils, climate and water, has about 80 objects of nature

${ }^{14}$ Ritchie B., Crouch. G.(2003). The competitive destination: a sustainable tourism perspective. Cambridge: CAB International, $291 \mathrm{p}$.

${ }^{15}$ Cooper C., Fletcher J., Gilbert D., Shepherd R., Wanhill. S.(2005). Tourism: Principles and practices 1. Harlow : Pearson, $736 \mathrm{p}$.

${ }^{16}$ Framke W. (2002).The Destination as a Concept: A Discussion of the Businessrelated Perspective versus the Socio-cultural Approach in Tourism Theory. Scandinavian Journal of Hospitality and Touris, № 2(2). 
reserves of national, international and local importance ${ }^{17}$. The region is washed by the Black and Azov Seas, as well as the Kakhovka Reservoir and Lake Sivash. Unique natural highlights on the territory of the destination are biosphere reserves: Black Sea Biosphere Reserve - the epicenter of nesting, migratory and winter clusters of birds of the Black Sea coast; Askania-Nova Biosphere Reserve - the only primary steppe in the world that has never been used for agriculture and where American bison, camphor buffaloes, saigas, llamas, Scottish ponies, wild horses, mouflons, ostriches and camels, antelopes, deer, pheasants, peacocks, pink pelicans, black-headed gulls, swans and other rare representatives of fauna and flora can be found. In addition, there are five national nature parks in the region: Azov-Sivasky, Oleshkivsky Pisky, Dzharilgatsky, Nizhnedniprovsky and Kamyanska Sich (which is in the process of being created).

The unique objects of Kherson region are thermal springs: a healing geyser in the village of Obloi of Holoprystan district, Lemuria lake in the village of Hryhorivka, Chaplynskyi district and a hot spring on Arabatska Strelka. They are rare in their natural and medicinal properties and attract many tourists from all regions of Ukraine as well as foreign tourists.

Among the most attractive parts of the Kherson region is ecologically clean Delta of the Dnieper, the world's largest man-made forest 100 thousand hectares. Today, two European-class yacht clubs "MaximMarine" and "Katrin" operate in the waters of the Dnieper in the city of Nova Kakhovka. On the territory of Kherson region there are a number of tourist infrastructure facilities that promote the development of green tourism, such as: fishing and recreation complex "Delta Dnieper", green tourism base "Seagull", recreation center "Zburyivsky Kut", the suburban complex "Grand Prix", Green estate "Fairy Tale Oleshsha", estate "Trophy", restaurant "Pan Ataman", winery of Prince Trubetskoy, etc. Every year more than 3.5 million guests visit Kherson region. More than 1000 objects of rest, improvement, accommodation (among them - 53 for children, 62 estates of green tourism, 51 hotel complex) are involved in process of rendering of tourist services to clients.

The richness of the region is also enhanced by the rich festival calendar of Kherson region - the international festival of theatrical premieres "Melpomene of Tavria", "Tavria Farms", "Black Sea Games", "Kupalski Stars", "Ukrainian Watermelon - Sweet Miracle" and many others.

${ }^{17}$ Official web-site of the Kherson regional state administration. Turystychnyi ta rekreatsiinyi potentsial. [Tourist and recreational potential]. URL: https://khoda.gov.ua/ turistichnij-ta-rekreacijno-kurortnij-potencial/ (accessed: 11 March 2021). 
The current Internet resources also contribute to the promotion of tourist services and the formation of the image of the territory: Official site of the Department of Tourism and Resorts of the Kherson Regional State Administration; Official tourist portal; Tourist guide to Kherson; Travel through the Kherson region; Everything about tourism, souvenirs, entertainment; Kherson Tourist Region; Virtual Kherson; Internet portal (vacation on the Black and Azov Seas).

Today the region is actively developing health, water, wine, historical and cultural tourism. Thus, considering the destination according to the available tourist potential, it is possible to position the region by specialization as multifunctional, which has significant resources of different types and attracts tourist flows with different chains. At the same time, the Kherson region should take into account the trends in the development of ecological and green tourism around the world, which is associated with the exacerbation of environmental problems. Increasingly, promotional events and eco-tours are held, which include recreation and spending time in the natural environment, without polluting it and without causing harm. This problem also applies to Ukrainian tour operators at both the national and regional levels. With this in mind, we investigated the need of consumers in ecological and green tourism for consumers in the Kherson region. Despite the favorable position of the destination for tourism, rest, health and recreation, the potential of green (ecotourism) of Kherson region is not used to full capacity and needs development. This is due to a number of difficulties and certain obstacles that have arisen as a result of the pandemic and, as a result, the fears of tourists. At the same time, the development and promotion of individual (in microgroups) green routes and presenting them to consumers as a means of recreation and isolation from the noisy city, from large crowds is a promising direction and can bring significant profits to tour operators and promote development of the territory.

To develop measures to intensify the "green routes", we found out the opinion of customers in relation to eco-tourism and studied their preferences for the services provided by tour operators in the Kherson region. Field research continued during September-October 2020 through a structured questionnaire. The opinion of the residents was represented by respondents who were part of the formed one-stage probabilistic non-repeated quota sample $(\mathrm{n}=100$ people, accuracy $10 \%)$. Gender, age, education, field of activity, income level and family size of the respondents were chosen as the criteria of the target client from among the characteristics of the consumer. Of the total sample (100 people), we interviewed $52 \%$ of women and $48 \%$ of men; by age characteristics, we interviewed $45 \%$ of people aged 18-30, $25 \%$ of people aged $46-60,18 \%$ aged $31-45$ and $12 \%$ aged 61 and older; $52.8 \%$ of the respondents had an income level of UAH 6001-8000, 20\% UAH 4001-7999, 22\% - UAH 8001 and more, 5.2\% - UAH 18,000-3999; 
The largest share in the field of activity among respondents were technical performers $(34 \%)$ and specialists $(25 \%)$, managers $(11 \%)$, retirees $(4 \%)$ and students (26\%). According to the survey, eco-tourism services, in contrast to traditional ones, are preferred by $44.4 \%$ of respondents, a certain share of whom $(20.2 \%)$ choose them as a means to isolate themselves from crowds and the hectic pace of urban life; $9.4, \%$ - due to the possibility to combine recreation with active amateur travel; $6.1 \%$ - due to the desire to relax in nature and communicate with the living world; $4,2 \%$ - for the rest of the family; $3 \%$ - for the purpose of sports tourism and the use of a cheaper accommodation; 1,5 - with other priority goals. But the majority (55.6\%) of respondents said that they have used eco-tourism services only a few times, because their priority is safety, leisure and quality of service. Problematic points were identified: the lack of marked routes; poor preparation of rural roads for the passage of ecological bicycle paths; lack of equipped places for rest and service workshops in the territories through which "green routes" pass; insufficient advertising support based on health, safety, involvement, selfaffirmation, which is an important tool in the geomarketing of eco-tourism.

In view of this, tour operators today should pay more attention to the ecological walking zone "wildlife": to arrange eco-tourist trails, places of observation and recreation, to develop active sports, even extreme and adventure; to arrange elements of life and sanitation; to develop marketing of eco-tourism, increasing advertising support and finding the necessary form of delivery to the addressee of the advertising appeal through the formation of his social responsibility and demand for eco-tourism. Solving these issues will increase the attractiveness of eco-tourism services for customers and will promote the development of tourist and recreational potential of Kherson region.

The development of the destination brand program must be based on the unique resources and values of the area or events that have occurred or are planned to occur over a period of time. The measures that can be presented in the program are: research and analysis of the tourism market by tracking feedback from consumers and assessing their response to a range of goods and services provided to customers in the region; organization of events for the presentation of the region both nationally and internationally; popularization of a tourist destination by developing and implementing promotional campaigns for key segments, promotion in the channels of information and sales used by tourists - media, airlines, tour operators, bloggers, Ukrainian missions abroad, international organizations, partner cities, etc.; development, production, purchase of tourist information, promotional printing and souvenir products, video and photo materials; promoting the creation and promotion of new competitive tourism products, tourism topics; increasing the attractiveness of public space, breeding tourist flows, expanding the 
boundaries of the tourist center; development of business hospitality; reception and service of representatives and delegations of the tourism industry and mass media from Ukraine and abroad; raising the level of awareness of residents and tourists about tourist services and activities through the placement of information in the media; assistance in holding a competition of socio-cultural projects of public organizations in the field of tourism and support of other initiatives of representatives of the tourism cluster; promoting the exchange of social advertising with other cities, towns, regions in Ukraine and abroad ${ }^{18}$.

When developing a destination brand development program, it is necessary to take into account certain changes that have occurred in the moods, values, priorities, behavior of consumers to offer them new, or changed, relevant products and services. In today's reality, consumers are more selective in spending time and being active, which allows them to behave freely, focusing on what they really want and what they get functional and psychological satisfaction from.

If consumers used to rely on a particular brand or professional source of information to get what they wanted, now companies need to constantly innovate, lower prices and optimize offerings to attract customers. This trend is based on the obsessive need of people to absorb and share information, including through social networks. It is no longer possible to hide important information about a product or service from consumers; everything is subject to doubt and verification. This necessitates the use of other modern marketing tools in addition to branding technologies: Internet marketing, content marketing, event marketing, neuromarketing, etc., which will form the consumer's commitment to the brand's perception of the region.

Thus, taking into account the established trends, local authorities should involve as many interested stakeholders as possible in the formation of the Kherson region brand: producers of wines and food products, both traditional and craft, souvenirs and creative handmade products, representatives of relevant associations such as Public Association "Association of Kherson Watermelon Producers", Association "Regional Tourist Organization "Tourism of Kherson", civil organization "ChefsClub" Association of Chefs of the South, tour operators and agencies, farmsteads of rural green tourism, educational and scientific institutions, catering and accommodation. Possible potential ways to unite the participating partners need to be explored, which

${ }^{18}$ Muzychenko-Kozlovska O.V. (2016) Metodyka otsiniuvannia turystychnoho brendynhu destynatsii [Methods for evaluating tourist branding of destinations]. Visnyk NU : Lvivska politekhnika. Lohistyka [Bulletin of Lviv Polytechnic National University. Logistics]. № 846, pp. 120-125. 
will expand and improve the system of geographical indications and help attract tourists, as well as the overall economic, cultural and social development of the Kherson region. To consolidate the partners, the regional leadership needs to establish consulting and methodological support and provide practical assistance in the formation, promotion and sale of competitive goods and services provided by producers of the region and form the image of the region. Interaction is extremely necessary in the following key areas: marketing technologies (marketing research, branding of the territory, digital marketing, video content, exhibitions, events, production of printed promotional materials, social marketing, co-branding, etc.); high quality of products and services through the introduction and observance of quality systems that meet world and European standards; raising the level of knowledge and professionalism of staff (organization of trainings and training programs on world best practices; seminars, conferences and round tables, organization of competitions, participation in grants, youth and human capital development programs, support for youth entrepreneurship, cooperation with higher education institutions, publications professional literature and translation of foreign sources); statistics (collection and analysis of static data, sociological research in the region); networking (representation of business interests in relations with the authorities, organization of business meetings and events, internal cross-business communications of various industries in the region and cross-cultural communications with business stakeholders, formation of regional networks by areas); measures of people's diplomacy (involvement of the local population in the development of the region, creation of a loyalty program (Brand Kherson region - the steppe southern pearl of Ukraine).

\section{CONCLUSIONS}

Thus, the analysis of the experience of management and marketing in the field of business allows drawing certain conclusions for other areas, including in the field of territorial management. In our opinion, strategic planning plays a significant role in the development of the territory as an important tool to increase its competitiveness.

The methodology of work on the development of a strategic plan to increase the competitiveness of the territory should include the following stages:

- organizational work (determination of geographical boundaries of the settlement; creation of a strategic development committee, the composition of which should adequately reflect the structure of the region and all stakeholders: authorities, private companies, research institutions, etc.; coordination of strategy development schedule, which is a management tool and developed to ensure the timely implementation of the project); 
- analytical work (conducting a thorough analysis of the development of major industries and sectors of the economy; compiling the economic profile of the region; conducting a survey of entrepreneurs and government officials and the public; identifying the main sectors of the economy, areas of development and their analysis; determination of priorities of settlement development (main sectors (industries) and directions of economic development; SWOT, PEST - analysis in terms of directions of development and selected sectors; determination of strategic vision of the settlement and its mission);

- planning work (drawing up an action plan in terms of areas of development and the main sectors of the economy of the settlement; determining the list of projects);

- work on the implementation of the plan (determination of bodies responsible for the implementation of the strategic plan; development of the budget for the implementation of each project; approval of the plan by the territorial community; creation of bodies to manage the implementation and monitoring of the strategic development plan).

Thus, the main thing in ensuring effective management of territories is to study the specific conditions of their activities and their leaders as professional managers, modern techniques and methods of management and effective tools of marketing management that will promote regional development and increase their competitive potential.

For the formation and development of the brand of the territory it is necessary to take into account the material and technical component and attract investment for system-forming objects; to develop a scheme of perspective location of transport and logistics infrastructure; to provide the necessary means to create a modern hotel and service system for accommodation and meals for visitors, a network of tourist complexes, recreation areas and create conditions there that meet international standards; resort to branding technologies and the latest tools of digital marketing in order to promote the region and form a favorable image of the territory in the minds of consumers.

\section{SUMMARY}

The article examines the theoretical and practical aspects of regional development based on modern approaches to management and marketing in the face of global challenges and threats. The main competencies that a professional manager should possess when determining the strategic directions of territorial development and making decisions on the formation of the brand of the region are considered. The main stages of developing a strategic plan to increase the competitiveness of the territory are identified. An assessment of the potential of the tourist destination of Kherson region is presented and the main measures for its development to strengthen the brand of the region are outlined. 


\section{REFERENCES}

1. Lanza A., Markandya A., Pigliaru F. (2005) The Economics of Tourism and Sustainable Development. Cheltenham, UK; Northampton, MA, USA. P. 8.

2. Bilenchuk P.D., Kravchenko V.V., Pidmogilny M.V.(2000) Mistseve samovriaduvannia v Ukraini [Local self-government in Ukraine]. Munitsypalne pravo [Municipal law]. Kyiv : Atika, 304 p.

3. Chemeris A.O., Shevchuk P.I., Gural P.F.(2002) Mistseve samovriaduvannia: Monohrafiia. Kn.1. Orhanizatsiia roboty silskoho, selyshchnoho holovyLviv: [Local government: Monograph. Book 1. Organization of work of the village, settlement head]. Lviv : Liha-Pres, $390 \mathrm{p}$.

4. Rehionalne upravlinnia: pidruchnyk /za zah. red. Yu.V. Kovbasiuka, V.M. Vakulenka, M.K. Orlatoho ta in. (2014) [Regional management: a textbook/for general. ed. Yu.V. Kovbasyuk, V.M. Vakulenko, M.K. Orlatogo and others]. K. : NADU, 740 p.

5. Bozhkova V.V. (2005) Zastosuvannia nekomertsiinoho marketynhu na munitsypalnomu ta rehionalnomu rivniakh [Application of non-commercial marketing at the municipal and regional levels]. Marketynh $i$ reklama [Marketing and advertising]. № 9, pp. 38-43.

6. Anholt S. Competitive Identity: The New Brand Management for Nations, Cities and Regions. 1-st edition. Palgrave Macmillan, 2007, 160 p.

7. Anholt S. Places: Identity, Image and Reputation. Palgrave Macmillan, $2009,256 \mathrm{p}$.

8. Kotler F., Asplund K., Raine I., Haider D.(2005). Marketynh mest. Privlechenie investiczij, predpriyatij, zhitelej i turistov v goroda, kommuny', regiony`i strany` Evropy [Place marketing. Attracting investments, enterprises, residents and tourists to cities, communes, regions and countries of Europe]. SPb. : "Stokgol`mskaya shkola e'konomiki", 382 p.

9. Baker B.(2007) Destination Branding for Small Cities. [1st edition]. Creative Leap Books, 192 p.

10. Dinnie K. (2011) City Branding: Theory and Cases.[1 edition]. Palgrave Macmillan. 2011, 256 p.

11. Govers R., Go Fr.(2009) Place Branding: Glocal, Virtual and Physical Identities, Constructed, Imagined and Experienced. Palgrave Macmillan. 2009, 256 p.

12. Moilanen T., Rainisto S.(209) How to Brand Nations, Cities and Destinations: A Planning Book for Place Branding. Palgrave Macmillan, 2009, $230 \mathrm{p}$.

13. Pike St. (2008) Destination Marketing: An Integrated Marketing Communication Approach. Butterworth-Heinneman, $424 \mathrm{p}$.

14. Ritchie B., Crouch. G.(2003). The competitive destination: a sustainable tourism perspective. Cambridge : CAB International, $291 \mathrm{p}$. 
15. Cooper C., Fletcher J., Gilbert D., Shepherd R., Wanhill. S. (2005). Tourism: Principles and practices 1. Harlow: Pearson, 736 p.

16. Framke W. (2002). The Destination as a Concept: A Discussion of the Business-related Perspective versus the Socio-cultural Approach in Tourism Theory. Scandinavian Journal of Hospitality and Touris, No2(2).

17. Official web-site of the Kherson regional state administration. Turystychnyi ta rekreatsiinyi potentsial. [Tourist and recreational potential]. URL: https://khoda.gov.ua/turistichnij-ta-rekreacijno-kurortnij-potencial/ (accessed: 11 March 2021).

18. Muzychenko-Kozlovska O.V. (2016) Metodyka otsiniuvannia turystychnoho brendynhu destynatsii [Methods for evaluating tourist branding of destinations]. Visnyk $N U$ :Lvivska politekhnika. Lohistyka [Bulletin of Lviv Polytechnic National University. Logistics]. № 846, pp. 120-125.

\section{Information about the author: \\ Bolila Svetlana Yuriivna,}

$\mathrm{PhD}$ in Agriculture, Associate Professor at the Department of Management and Information Technologies Kherson State Agrarian and Economic University 23, Stritenska str., Kherson, Ukraine, 73006 orcid.org/0000-0002-9689-6774 